\title{
Women's Rights in the Vajrayāna Tradition
}

JAMPA TSEDROEN (CAROLA ROLOFF)

As a Buddhist nun practicing in the Tibetan tradition I would rather prefer to speak on Human Rights in Tibetan Buddhism than in the wider Vajrayāna tradition, because on the one hand the Vajrayāna is also practiced in Japanese Shingon and Nepalese Newar Buddhism, neither of which I am familiar with. On the other hand this gives me the opportunity to approach the topic from a broader perspective without restricting myself to tantric Buddhism. Thus I will approach the topic of human rights from a Tibetan Buddhist perspective, showing how the universalism of human rights can be deduced from traditional theories that constitute the doctrinal basis of Tibetan Buddhism. Furthermore, since the organizers of the symposium have asked me to link the topic of human rights in Vajrayāna to the First International Conference on Buddhist Womens' Role in the Sangha, ${ }^{1}$ which took place at the University of Hamburg in 2007, I will show that in the context of discussions of human rights, from a Western understanding, it cannot go unmentioned that these theories are not always rigorously applied. This will be made clear using the example of women's rights, which are not consequentially observed in any Buddhist tradition so far. During the Hamburg conference H. H. the Fourteenth Dalai Lama, among

1 Skr. sangha (Tib. dge 'dun) has here the meaning of monastic order. A selected proceedings of the conference will be published under the title Dignity and Discipline. The Evolving Role of Women in Buddhism by Wisdom Publications (Boston) in 2009. 
other outstanding speakers, spoke on "Human Rights and the Status of Women in Buddhism", while the Protestant bishop Maria Jepsen presented a paper on "Women and Religion: The religious competence of women". ${ }^{2}$ The discussions during the conference showed that if Buddhism in the 21st century is to remain credible, it must soon reposition itself on this issue. Although it is important to respect various cultures and religions, women's rights can not be relativized, but rather the world community needs to follow the universal principles already laid down and ratified by all the Asian countries where Buddhism is widespread.

\section{Ways of Approaching a Western Understanding of Human Rights From a Buddhist Perspective}

For the 60th Anniversary of the Universal Declaration of Human Rights, the Dalai Lama wrote:

Internationally, our rich diversity of cultures and religions should help to strengthen fundamental human rights in all communities. Underlying this diversity are basic human principles that bind us all together as members of the same human family. The question of human rights is so fundamentally important that there should be no difference of views about it. We all have common human needs and concerns. We all seek happiness and try to avoid suffering regardless of our race, religion, sex or social status. However, mere maintenance of a diversity of traditions should never justify the violations of human rights. Thus, discrimination against persons of different races, against women, and against weaker sections of society may be traditional in some regions, but if they are inconsistent with universally recognized human rights, these forms of behavior should change. The universal principle of the equality of all human beings must take precedence. ${ }^{3}$

On what should a potential universalism of human rights be based? In June 1993, during the Human Rights Conference of the United Nations in Vienna, H.H. the Fourteenth Dalai Lama explained before a gathering of NGOs that for him, the key to creating a better and more peaceful world is the development of love and compassion for others. He stated that "universal responsibility is

2 For the detailed program of the conference see http://www. congress-on-buddhist-women.org (accessed on August 12, 2009).

3 Dalai Lama 2008. 
the best foundation for world peace". ${ }^{4}$ Tibetan Buddhism offers a variety of approaches to conflict resolution and respect for human rights and women's rights.

\title{
Universal Responsibility, a Key Notion of Buddhist Mind Training
}

\begin{abstract}
"Universal Responsibility" has come to define the Dalai Lama's sense of human interrelatedness and compassion, which goes beyond all national borders. He reminds us that we are all members of a large human family and encourages human beings to develop a sense of responsibility for each and every member of this community. This advice is based on a central concept of the Buddhist mind training in the Mahāyāna: the "exceptional attitude" (Tib. lhag bsam). By developing love and compassion, one comes to the decision to take upon oneself the responsibility to strive for the well-being of others and relieve their suffering. Thus arises bodhicitta, the aspiration for enlightenment for the benefit of all beings. In Tibetan Buddhism, two methods for developing bodhicitta are explained. Both are based on "equanimity" (Tib. btang snyoms; Skr. upekșa ), an impartial, unwavering attitude that is free from attachment and aversion, and beyond distinctions of friend and enemy. 5
\end{abstract}

\section{Equanimity, Respect and Appreciation for Others}

Equanimity is the sense that all beings are of equal value. This attitude is free of hostility towards others, or strangers, and free from attachment or fixation based solely on one's own interests and the interests of those close to one. Based on the theory of "dependent origination," one should consider how dependent human beings

4 Dalai Lama 1993.

5 A similar method, closely related to universal responsibility, that is taught by all Buddhist traditions, is meditation on the four boundless attitudes: equanimity, love, compassion, and joy. Cf. Ngawang 1995, pp. 78-91. One can use this technique to prevent tendencies to violence, as well as to strengthen tolerance, respect, appreciation, and sympathy. 
are on one another and therefore how much one owes to others. In this way, one develops respect and esteem for them. This is difficult to practice when others do harm in the world, for example, through violence and torture. Nevertheless, attempts are made not to give up even on these people and to make oneself aware that they are similar to oneself in their desire to gain happiness and avoid suffering. It is just due to ignorance that they think and act wrongly. This does not mean that one simply sits back and tolerates their actions. But one strives to see things from the other's perspective and tries not to react with hatred and violence. In a spirit of dialogue, one recognizes the problem and attempts to respond in an altruistic and skillful way. The aim is to minimize harm and maximize the benefit for all parties involved.

\section{Exchanging Self and Others}

These abilities can be developed through a meditation method called "exchanging self and others". One tries to imagine oneself in the place of others, and behaves accordingly. This meditation can be combined with mindfulness of one's own breathing. With each inhalation, one imagines breathing in the sufferings of others and the causes of their suffering. With each exhalation, one imagines sending them well-being, prosperity, and the benefit of all one's positive factors actions. This technique is called "giving and taking" (Tib. gtong len). Generosity is one of the most important Buddhist virtues. It is not limited to material generosity, but also includes broadminded thinking, the sharing of knowledge, and personal social engagement, e.g., working for human rights and women's rights.

\section{Tradition versus Modernity}

These practices, all based on the traditional doctrinal foundations of Mahāyāna Buddhism, are suitable points of entry in dialogue with Western understandings of human rights. From the perspective of research on Buddhism, however, it is notable that neither the term nor the concept of human rights is explicitly found in Buddhist texts. In Asia, the concept is often associated with "modernity" and may be regarded as a "threat to the tradition" from a conservative point of view. 
Nevertheless, according to the website of the United Nations, ${ }^{6}$ all the countries where Buddhism is widespread have already ratified the most important documents on human rights, such as the Universal Declaration of Human Rights of 1948 and the Convention on the Elimination of All Forms of Discrimination against Women of 1979. Hence, the question of whether human rights are universal is, in fact, too late. All human beings have these same rights, regardless of race, origin, social status, gender, or other characteristics, and I assume that we all want to keep them. These documents are not much help, however, if their implementation is insufficient or lacking altogether.

The Tibetan translation of "human rights" in modern Tibetan is mi'i thob thang. Although the term thob thang here means "right(s)," it implies something else, namely, a certain social position or privilege that is obtained. As in the rest of the world, in Tibetan society words such as thob thang 'dra mnyam ("equal rights") or bud med thob thang ("women's rights") are only used in the secular context, not in a religious context.

In Tibetan Buddhist institutions, all the leading offices are held by men. There are no female monastic academic titles equivalent to geshe (Tib. dge bshes, lit. "friend of virtue, spiritual guide") or khenpo (Tib. mkhan po, lit. "teacher, preceptor"), and classes in Buddhist philosophy even at the Central Institute of Higher Tibetan Studies in Sarnath, India, are taught only by monks. In 2005, at a meeting of the Tibetan Nuns' Project, twenty novices from eight Tibetan nunneries decided to pursue their efforts to follow through with full ordination. Tibetan Buddhist novice nuns at Jangchub Choeling Nunnery in Karnataka State, India, were supposed to receive the same title as monks receive after receiving education and training for up to 17 years. So far about fourteen nuns successfully completed their studies in the years 2006 to 2009, but they have not received any final academic title yet. Earlier, some high-ranking monks stated that they would do everything to ensure that the nuns' accomplishments were recognized, while others stated that they will know to avoid them as long as they are alive. More recently, however, there have been allegations that religion and politics are being mixed and that women who seek full ordination or

6 http://www.ohchr.org, accessed on November 28, 2008. 
monastic academic titles are no longer seeking religious goals, but are after purely secular goals, such as fame and glory, which contradict monastic mores.

The situation is very different in Korea. There, nuns teach Buddhism at universities alongside monks and lay scholars. The statutes of the Jogye Order, the largest Buddhist congregation in Korea, are supposed to state in a figurative sense that monks may bow to nuns. ${ }^{7}$ In contrast, gender distinctions are still found in the Vietnamese and Chinese traditions, expressed in the different colors of their robes. Changes are rapidly occurring, however. The Australian Sangha Council, for example, includes gender equity in its statutes.

\section{Equal Opportunities and Buddha Nature}

In Tibetan circles, I personally decided only to speak about "equal opportunities" (Tib. go skabs gcig pa or go skabs 'dra mnyam) and not about "equal rights" or "equality". Nobody can blame women for expecting the same opportunities that men have for following the spiritual path towards liberation. In the Perfection of Wisdom Sütras (Skr. Prajñāpāramitāsūtra), a genre of Mahāyāna Buddhist scriptures, wisdom is designated the "mother of all Buddhas". Iconographically, the female bodhisattoa Prajñāpāramitā embodies the completion of highest wisdom and knowledge. Already in early Buddhism, the Buddha ensured that women can attain enlightenment in the body of a woman. He taught the same path to awakening for women and men. The minds of all sentient beings are said to equally possess Buddha nature, the potential to become a Buddha. In this regard, all human beings are equal, whether female or male. Buddhists of all traditions agree that the nature of the mind is the same for all, regardless of race, color, sex, language, religion, political ideolology, nationality, social origins, property, birth status, or other distinc-

7 During the 2009 International Conference for Buddhist Sangha Education - Exploration on the Education for Contemporary Buddhist Ordained Women organized by the Luminary Buddhist Institute, Chia-I Hsien, Taiwan, in Taipei, May 30th to 31th of 2009, a leading Korean nunscholar explained to me that the statutes rather state that the bhiksunis observe the precepts of bhikșus to enable them to take over the same offices monks do. This needs further research. 
tions. Sometimes sentient beings are born female and sometimes male. The concept of evolution from a lower form as a woman to a higher form as a man does not exist. There is also no guarantee when one dies as to where one will be reborn. The Tibetan lam rim teachings ("Stages of the Path") speak of a precious human birth, not of a precious female birth or a precious male birth. Such a distinction would be seen as an obstacle on the way to liberation.

In general, religious identity is largely decided by where one is reborn. For example, one can be born in a "central country" (Tib. yul dbus; Skr. magadha) where the teachings of the Buddha flourish or in an isolated, uncultured country where there is no living dharma tradition. But being born into a religious tradition does not mean that one is necessarily a religious person or a follower of that religion. In order to become a Buddhist, one needs to take refuge in the Buddha, his teachings, and his community. ${ }^{8}$

Attachment to rigid religious views is considered a danger to spiritual development, especially for monastics. Attachment to views is considered a common reason for disputes. At the 10th Sakyadhita International Conference on Buddhist Women in Mongolia (2008), the American nun Karma Lekshe Tsomo said that religious identity or identification is potentially harmful if it creates attachment or aversion to specific religious traditions, in which case it becomes a potential source of conflict and violence. Therefore, from a Buddhist perspective, attachment, aversion, conflict, and violence are all to be avoided.

\section{Nonviolence and the Universality of Human Rights}

"Nonviolence" (Tib. mi 'tshe ba; Skr. ahimsā) and "dependent origination" (Tib. rten cing 'brel bar 'byung ba; Skr. pratityasamutpāda) are the two main pillars of Buddhism. Nonviolence is the basis for the ethics of love and compassion. It includes not only non-violation, but also altruism and self-sacrifice. The Dalai Lama defines nonviolence as the wish that beings be free from suffering and actively take responsibility for the welfare of others. For decades, the Dalai Lama has advocated the universality of human rights. Considering what has

8 Tsomo 2008. 
happened to his people in Tibet, one is surprised that the People's Republic of China has ratified the Universal Declaration of Human Rights. Not only has China received massive criticism for its lack of implementation of the Declaration, but China also holds the world record as the country that carries out the most executions. In Tibet, arbitrary arrests, mistreatment, and torture are the order of the day.

\section{Women's Rights Can Not Be Relativized}

If the human rights of a nation or state are violated, it does not necessarily mean that its government or its citizens are always well behaved or respectful of human rights. The Universal Declaration of Human Rights seems to function as a kind of legal counterbalance that enables world citizens to address violations of human rights. The same goes for the Convention on the Elimination of All Forms of Discrimination against Women. Both, without exception, are violated in all countries where Buddhism is widespread, even though their governments have signed onto the Convention. One need only think of domestic violence or child trafficking in Thailand. Therefore, particularly at the Fourth World Conference on Women in Beijing in 1995, the culturally and historically different understandings of women's rights were fiercely contested. Gender equity is still not self-evident in the politics, economics, and societies of the world. This is partly the fault of the world's religions. For example, it is known that the Vatican often concurs with Islamic conservatives when it comes to the definition of women's rights.

In the fields of political science, philosophy, and sociology, there are many studies on women's rights. But there are still very few in the field of religious studies, including Buddhism. One observes with concern how religious fundamentalist activities increase worldwide. Certainly not only religions, but philosophies, ideologies, and political theories put forth claims to ultimate truth. But nowhere is the conflict as great as between the advocates of women's rights and certain religious traditions. Each tradition has its priorities concerning human rights, women's rights, and religious rights. What can be done when the world's religious traditions lag behind in their understandings of human rights and assign women a position subordinate to men? Many women are denied equal participation in religious life, the study and practice of their religion, espe- 
cially when ritual is involved. But to deny women the right to exercise shared responsibility for their religions is archaic.

This problem became particularly significant in the framework of the Vienna Declaration on the Elimination of Violence against Women of 1993. Although it should actually be a matter of course, it was noted that women's rights are an inalienable and indivisible aspect of universal human rights, and, in any case, cannot be relativized with reference to cultural and traditional mores. Acts of violence against women were explicitly condemned as human rights violations, including physical and sexual violence in the household and the family. Until then, women were accorded their "privacy,", which according to Article 18 of the Universal Declaration of Human Rights needs to be protected, together with religious freedom.

\section{The 2007 International Congress on Buddhist Women's Role in the Sangha at Hamburg University}

It is interesting to observe how Western women react when they have converted to a religion that has been imported from a foreign cultural environment and have taken gender equity for granted, but slowly note that theory and practice differ from each other, for example, in Buddhism. The International Congress on Buddhist Women's Role in the Sangha ("Order") at the University of Hamburg in 2007 was concerned with the full ordination of nuns (Skr. bhikșini). This level of ordination has only survived in some countries, such as Korea, Taiwan and Vietnam, but not in the Theravāda and Tibetan traditions. In a world that aims for gender equity, Buddhism is compromised if it does not take a clear and positive position on this issue. During the Congress, the Dalai Lama "outed" himself as a feminist, who has advocated for the equality of women since the 1960s. He made clear that he supports the revival of the full ordination for women as bhiksuniss, but cannot move forward alone, without a consensus among the majority of the monks. The Tibetan Prime Minister, Samdhong Rinpoche, who is also a monk, has said that all previously proposed solutions by competent bodies have been rejected.

9 Cf. Klingebiel 1995. 


\section{Buddhist Feminism}

Today, the Buddhist traditions have no choice but to acknowledge that the social roles of women have changed over millennia. It is not acceptable that in the 21st century Buddhism fails to live up to what the Buddha himself allowed a long time ago. But that is exactly what has happened. Some monks argue that the Buddha did not want an order of nuns and only agreed because his favorite disciple Ānanda pushed him to establish it. Another claim is that Asian women are not interested in equity and that even the Dalai Lama only advocates it because some Western feminists have pressed him on the issue. Already during the First Council held shortly after the death of the Buddha, Ānanda was criticized because he had favored the founding of the order of nuns. The effects of this criticism have been handed down until today.

However, senior representatives of the Buddhist traditions do not deny that conflicts have arisen between ancient traditions and lived secular conventions. The Buddha always paid attention to prevailing social views. During the Hamburg Congress, on a number of occasions, people asked what the Buddha would say about the role of women if he were interviewed today. The answer is clear. Already around 2500 years ago, the Buddha declined to support the caste system in India. Women belonged to all castes, in which they always took a back seat. Although the Buddha was not explicitly a social reformer, he certainly did not want to create two new castes of women and men. Discrimination is an issue for those who consciously experience it and it always entails suffering. Whoever causes suffering to others is no longer a follower of the Buddhist principle of nonviolence.

Buddhism is a religion that has canonical support for equality between women and men, so gender equity is in the spirit of the original teachings of the founder. At the time of the Buddha, the social freedom of women was very limited. Compared with men, they were considered to be of minor value, and both physically and socially inferior. Their purported inferiority was increasingly interpreted as a spiritual inferiority. Speculation about the limitations of female nature arose. The problem lies not in the doctrinal basis of Buddhism, but with those who are responsible for its practice. They 
have the obligation to apply the doctrine as it was intended, even if that means challenging the rigidities of established traditions. ${ }^{10} \mathrm{Ul}-$ timately it is a matter of going back to the roots, the earliest sources, and reinterpreting the texts in accordance with contemporary needs. A clarification would suffice, explaining how certain statements of the Buddha are to be understood in specific contexts. In keeping with the key concept of personal responsibility that is stressed in Buddhism, it is essential to consider the sources in their historical, social, cultural, and political contexts. A good approach is offered by Alan Sponberg in his essay “The Female in Early Buddhism". ${ }^{11}$

\section{Statements of the Buddha on Women and Their Potential for Enlightenment}

Sponberg suggests that the attempt to reconcile the various Buddhist sources with each other be abandoned, along with any attempt to justify contradictory and ambiguous statements of the Buddha. Instead, he emphasizes the importance of understanding the social and intellectual dynamics of the early Buddhist community. For him, the diversity of sources reflect diverse attitudes towards women and the feminine. The early canonical literature includes some statements about women attributed to the Buddha, but it is difficult to determine which statements actually originate from him.

It is important, nevertheless, that the Buddha is credited with clearly acknowledging women's potential for enlightenment, in the body of a woman, and taught both women and men, the same path to liberation. Gender and caste are no criteria. Already at the time of the Buddha, women had proved that they are equally capable of liberation as men. Buddhist texts tell of many female arhats (fully liberated beings). The Buddha praised laywomen and nuns as outstanding teachers and as highly realized beings. But it soon became necessary to regulate the rapid development of the order of nuns according to prevailing social standards and to legalize it through institutional structures.

10 Bodhi 2007.

11 Sponberg 1992. 


\section{Loss of Authority on the Part of the Order of Nuns by Institutional Suborder}

Women in ancient India lived under the protection of their father, brother, or son. Accordingly, the order of nuns was finally put under the "protection" of the order of monks. Sponberg suggests that the often-quoted passage on Mahāprajāpatī, the first woman who asked the Buddha to admit her to the order and who founded the order of nuns, not be taken literally, as a historic source, but be understood as a symbolic and mythical summary of an ongoing process. To become a nun, Mahāprajāpatī had to accept eight difficult rules. One of them says that a bhikșuni, even if already ordained one hundred years, must bow to a bhikșu, even if he has been fully ordained only a day. The establishment of an independent order of nuns had come under criticism and consequently was brought under the control of the order of monks. As a consequence, the order of the nuns lost prestige and material support. Soon it was deemed more meritorious to donate to monks than to nuns. In vain, Mahāprajāpatī asked the Buddha's permission for monks and nuns to render mutual respect to each other. In 2008, during the Annual Meeting of the American Academy of Religion in Chicago, Janet Gyatso, a Tibetologist at Harvard, made it clear that Mahāprajāpatī's attempts to ensure gender equity in the sangha demonstrate that feminist approaches are already evident in the Buddhist canon, not an innovation by Western women.

\section{Can Women Become Buddhas?}

Women were increasingly seen as a threat to male celibacy. But instead of identifying the source of the problem as the male renunciants themselves, responsibility was projected onto women. This misogyny is so evident in the tradition that it has been more carefully scrutinized than the androcentric view that led to the institutionalized subordination and devaluation of women in the first place. Sometime in the first century $\mathrm{CE}$, a dispute erupted as to whether women were equally capable as men in the achievement of "buddhahood". All Buddhist schools concurred that women were not. According to the Theravāda school, although women can obtain arhatship, the state of a Buddha like Sākyamuni can only be attained in the body of a man. And according to some Mahāyāna 
sources, women, at the time of attaining "buddhahood", by virtue of their achievement, must transform themselves into a man. ${ }^{12}$ Only from the 5th/6th century onwards, in Vajrayāna literature, is it explicitly stated that women can achieve the full enlightenment of a Buddha in the body of a woman. This capability is very clearly elucidated in the Tärā-tantra, for instance. The tantric teachings derive from both the early explication of the Buddha's teachings, which portray women and men equally travelling the path to liberation, as well as on the Perfection of Wisdom Sütras.

\section{International Pressure is Increasing}

In his essay "The Tyranny of Transcendence: Uses and Abuses in the Development of the Will," the Australian Theravāda monk Sujato points out that "equality for women" usually means that women should have equal pay or the right to vote. ${ }^{13}$ People are happy when they are given equal and fair treatment. But in a religious context, women meet strong resistance when they demand equal rights. Some Buddhist teachers advise them to be content and let go of such "worldly" concerns. One should not covet; therefore, one should not talk about obtaining rights. Emptiness and nirvāna (P. nibbāna) are beyond all these considerations. Nuns and monks have abandoned the worldly life and therefore should not be attached to property, titles, and entitlements. Such advice is egotistical and, in certain contexts, may even create and justify totalitarianism.

Allison Goodwin (2007) demonstrates parallels between the racial segregation of blacks and whites, and the separation of women and men. ${ }^{14}$ She reports from her own experience that in monasteries in Taiwan, she always had to sit behind men and was only allowed to speak after them. Based on psychological and social science research, she documented the impact that gender discrimination has on women's self-esteem. The effects are evident when women explicitly or implicitly are regarded as inferior and denied full equality, including the right to full ordination. The view that women are weak and karmically inferior to men is current not only in Taiwan, but throughout the Buddhist world.

12 Paul 1979.

13 Sujato 2008.

14 Cf. the film: "A Class Divided" (http://www.pbs.org/wgbh/ pages/frontline/shows/divided/), accessed November 28th, 2008. 
Buddhist practitioners typically meditate extensively. During intensive practice sessions, their teachers advise them not to think and not to study. This can lead to the perception that practitioners in the Buddhist community increasingly escape from ordinary responsibilities and almost maintain a cult of servility. Therefore, it is important to understand that there is no vow of obedience in Buddhism. This principle cannot be inferred even from the eight difficult rules for nuns. Sujato encourages women to take responsibility for themselves and for the teachings of the Buddha by actively opposing attempts to subordinate women, even if it becomes necessary to shift convent.

The Dalai Lama calls upon Buddhists to support human rights and women's rights. In a message to the 4 th Sakyadhita Conference in Ladakh 1995, he declared:

Our rich diversity of cultures and traditions should help to strengthen fundamental human rights in all communities. Mere tradition can never justify violations of human rights. Thus, discrimination against persons of a different race, against women, and against weaker sections of society may be traditional in some places, but because they are inconsistent with universally recognized human rights, these forms of behaviour should change. The universal principle of the equality of all human beings must take precedence. ${ }^{15}$

A comparison with the Dalai Lama's statement given above ${ }^{16}$ shows that he has not changed his mind on this essential point. But it is still made very clear that human rights and women's rights must be universal and should go beyond cultural and religious barriers.

\section{Practical Implementation on a Political Level and Impetus by Buddhism}

If one accepts that human rights are universal, these rights must also be valid in the field of religion. ${ }^{17}$ Here I would like to stress that

15 Dalai Lama 1995, cited by Goodwin 2007.

16 See p. 196 above.

17 Cf. the recent statement by 'The Elders' that "the justification of discrimination against women and girls on grounds of religion or tradition, as if it were prescribed by a higher authority, is unacceptable"; 
women's rights are not a matter of ensuring the protection of a minority, but of protecting the rights of $51 \%$ of the world's population. Now is the time for the world's religions to recognize that their traditions have contributed to and at least partially continue to ensure that women are disadvantaged in religions and in human society. For example, Bhikkhuni Dhammananda (formerly Chatsumarn Kabilsingh, a professor of philosophy at Thammasat University in Bangkok), contends that Buddhist attitudes support girl trafficking and prostitution in Thailand. ${ }^{18}$

Buddhism accepts that all suffering originates in the mind. Accordingly, the solution to gender inequities can just come from within. Whether we regard women and men as equals is a factor of our own thinking and religions still have an important influence on peoples' thinking. Were the world's religions to offer women equal opportunities in their institutions and provide them with equal responsibilities, this would go a long way in signalling to society that the subordination of women is no longer acceptable and would contribute to a rethinking of outmoded attitudes. Buddhist societies can contribute significantly to this rethinking.

On a political level, governments can organizationally include religious communities, but cannot dictate their contents. On the other hand, it is the duty of the state to ensure human rights for all its citizens. The observance of human rights cannot and should not be enforced with violence, but the control and monitoring of the observance of human rights statutes should not be left solely to the United Nations and human rights organizations. Most importantly, it should not spare religious institutions. Even if the claim to universal acceptance of human rights still does not correspond to social realities, this must not lead to their relativization, making out that human rights violations are justifiable due to cultural differences or religious preferences.

Furthermore, it is important to understand how religious thought and practice influence cultural activities and social developments in the course of history, and how social and historical developments influence religious thought and practice. On the one

online resource: http://www.theelders.org/media/mediareleases/ religious-and-traditional-practices-discriminate-against-women-andgirls, July 2nd, 2009, accessed August 13th, 2009. 
hand, religious practices inevitably change in new cultural contexts, which is a sign of the vitality and responsiveness of a tradition. This does not necessarily challenge the authenticity of the doctrine. On the other hand, uncritical acculturation of a tradition may transform it into something entirely different, indeed compromising its authenticity. This, of course, raises questions about how authenticity can be gauged, whether tradition is intrinsically valuable, and what is at stake in preserving tradition. For example, some Buddhist teachers in the West are teaching "feelgood Buddhism," minus any mention of ethics, death, rebirth, discipline, control of the mind, etc. On the other hand, the Buddhist orthodoxy of some schools renders them almost unapproachable and irrelevant, for example, on gender issues. ${ }^{19}$

Comparative cultural, historical and religious scientific considerations can help to strengthen this knowledge and build mutual understanding between East and West. Active dialogue between representatives from the fields of science and religion on human rights and women's rights in world religions and dialogical religious education in schools are needed. In the long term, on both the local and global levels, this can lead to a rethinking and consistent observation of human rights. Buddhism has proved to be flexible and useful in linking ideas in interfaith dialogue. It offers a variety of doctrinal foundations to approach the Western understanding of human rights and, in many respects, could have a stimulating effect.

19 Partly based on a personal communication with Ven. Karma Lekshe Tsomo, dated April 19th/20th, 2009. 